\title{
Applications of autologous platelet-rich plasma and adult stem cells for erectile dysfunction: current status and perspectives
}

\author{
Trung Quang $\mathrm{Ngo}^{1, *}$, Minh Hoang Truong ${ }^{1,2}$, Ngoc Kim Phan ${ }^{3}$
}

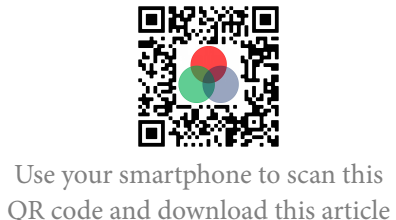

QR code and download this article

\begin{abstract}
Erectile dysfunction (ED) is one of the most common conditions affecting the sexual lives of middleaged and older men. The pathophysiology of penile erection is rather complex and concerns many specialists, such as andrologists, urologists, endocrinologists, and cardiologists. Recently, there has been a significant increase in our understanding of ED, detailed up to the gene and molecular level. Therefore, treatments for this disease are also more advanced and comprise numerous novel medications and therapies such as oral medications with phosphodiesterase type 5 inhibitor and modern penile prosthesis implantation. However, these therapeutic approaches have an impact in relieving the symptoms of ED and have not thoroughly resolved their reasons. Regenerative therapeutics including intracavernosal injection with platelet-rich plasma and stem cell therapy have gained considerable attention because of their ability to generate new penile tissue as well as reverse ED. The use of these novel ED treatments is emerging due to their safety and long-term efficacy based on substantial preclinical evidence. However, only a few clinical trials have been conducted and demonstrate promising outcomes. This article will briefly review the scientific evidence on these regenerative therapeutics for ED.
\end{abstract}

Key words: Erectile dysfunction, Platelet-rich plasma, Stem cell therapy

${ }^{1}$ Department of Urology and Renal Transplantation, People's hospital 115, 527 Su Van Hanh street, Ward 12, District 10, Ho Chi Minh city, Viet Nam

${ }^{2}$ Department of Urology, The University of Medicine Pham Ngoc Thach, Ho Chi Minh city, Viet Nam

${ }^{3}$ Stem Cell Institute, University of Science, Ho Chi Minh City, Viet Nam

Correspondence

Trung Quang Ngo, Department of Urology and Renal Transplantation, People's hospital 115, 527 Su Van Hanh street, Ward 12, District 10, Ho Chi Minh city, Viet Nam

Email: dr.ngoquangtrung@gmail.com

History

- Received: May 25, 2021

- Accepted: Oct 09, 2021

- Published: Oct 23, 2021

DOI : 10.15419/bmrat.v8i10.698

\section{Check for updates}

\section{Copyright}

(c) Biomedpress. This is an openaccess article distributed under the terms of the Creative Commons Attribution 4.0 International license.

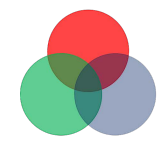

BioMedPress

The Open Access Publisher

\section{INTRODUCTION}

The four sequential phases in the sexual response cycle consist of desire, arousal, orgasm, and resolution. Erectile dysfunction (ED) is a disorder of the arousal phase and can be defined as the "inability to attain and/or maintain an erection sufficient for satisfactory sexual intercourse" ${ }^{1}$. An estimated 152 million men were affected by $\mathrm{ED}$ worldwide in 1995, and this figure is expected to increase to 322 million men by $2025^{2}$. According to the Massachusetts Male Aging Study (MMAS), the prevalence of ED was $52 \%$ in noninstitutionalized men aged $40-70^{3}$. The prevalence of ED increases as men age, and about $20-30 \%$ of adult men have at least one episode of sexual dysfunction ${ }^{4,5}$. Almost two-thirds of married men reported experiencing symptoms of $\mathrm{ED}$, and one-third reported having a low quality of life due to $\mathrm{ED}^{6}$.

The etiology of ED is quite complicated. Chronic comorbidities, vascular and metabolic syndromes, conditions of the nervous system, hormonal issues, medication use, psychological disorders, substance abuse, and certain sociodemographic factors are commonly associated with $\mathrm{ED}^{9}$. Diabetes, cardiovascular disease, and hypertension are all linked to an increased risk of ED and, as a result, a reduction in libido. The number of patients undergoing radical prostatectomy
(RP) due to localized prostate cancer has also been gradually increasing, leading to an escalating proportion of patients with postoperative ED. Additionally, several localized diseases may have a relation to $\mathrm{ED}$, such as Peyronie's disease (PD), which is characterized by plaque formation in the tunica albuginea ${ }^{10}$. Based on etiology, ED can be classified into organic, psychogenic, and mixed $\mathrm{ED}^{11}$ (Table 1). Erection is a neurovascular event that simultaneously involves neural integrity, a functional vascular system as well as healthy cavernosal tissues. An erection is established by three synergistic and synchronized phenomena: sinusoidal relaxation, arterial dilation, and venous compression. The corpora cavernosa, which consists of sinusoids covered by a layer of endothelial cells (ECs), a multilayer of cavernous smooth muscle cells (CSMCs), and the cavernous nerves (CNs), plays an integral role therein. ECs actively regulate basal vascular tone and vascular reactivity, responding to stimuli by releasing numerous relaxing and contracting factors that are inherently in equilibrium in the normal state. The contractile systems (RhoA/Rho-kinase, $\alpha$-adrenergic, endothelin, angiotensin, and thromboxane A2) oppose the vasodilatory second-messenger systems (adenylate cyclasecyclic AMP and guanylate cyclase-cyclic GMP) and participate in controlling cavernosal smooth muscle 


\section{Table 1: Classification of erectile dysfunction ${ }^{7}$}

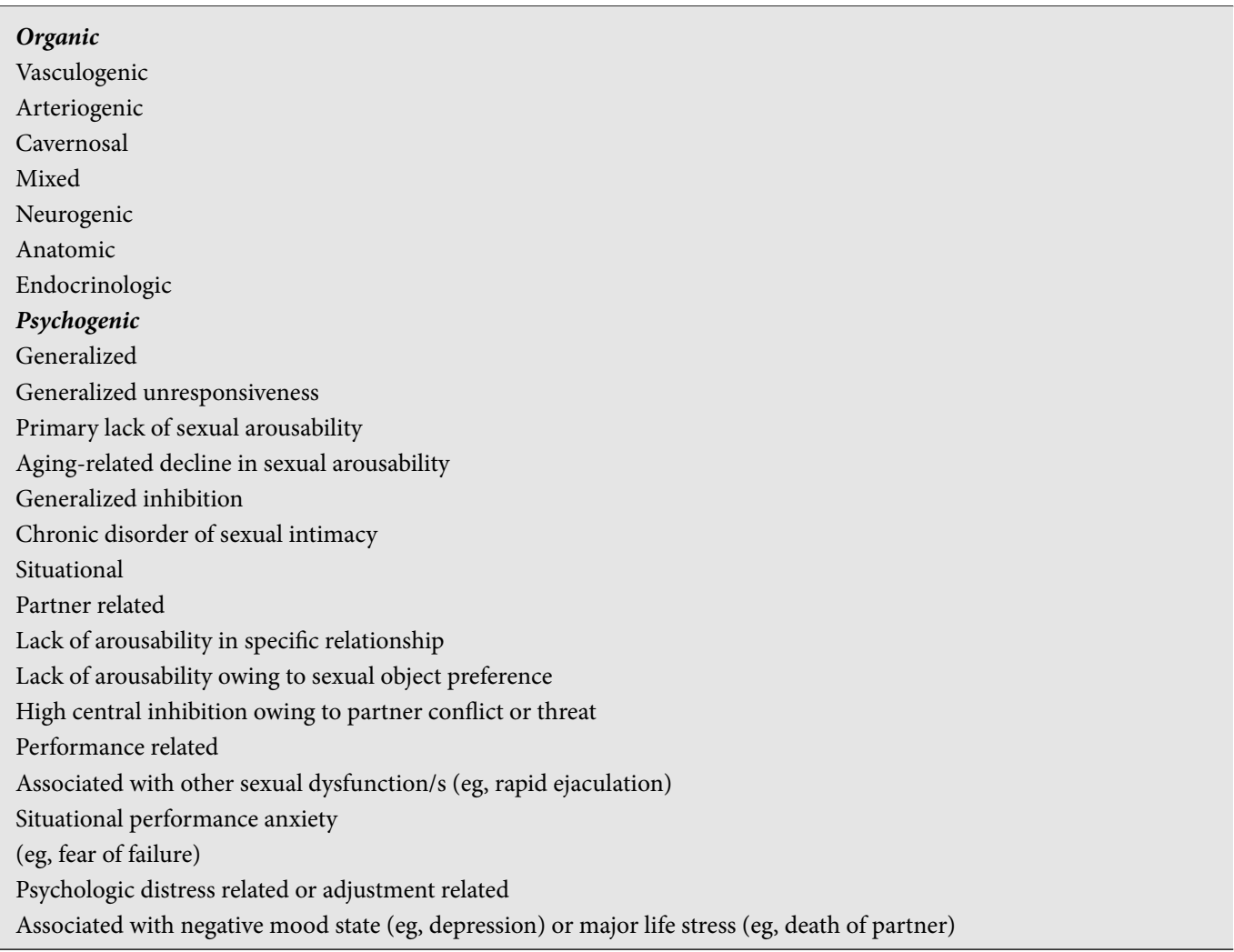

\section{Regulation of Smooth Muscle Relaxation and Effect of PDE5 inhibitors}

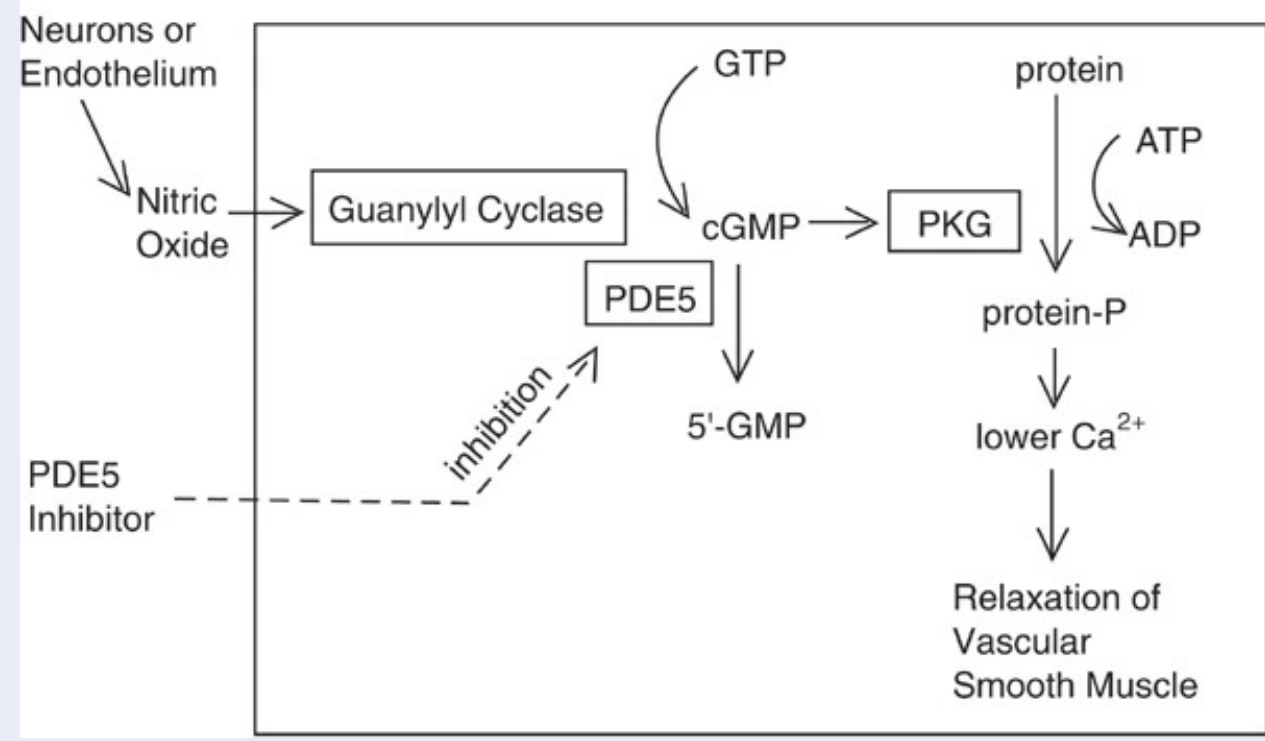

Figure 1: cGMPpathway for relaxation of smooth muscle ${ }^{8}$. NO from nerves and endothelial cells infiltrates into smooth muscle cells then binds to guanylyl cyclase that catalyzes the formation of 3 '-5'-cyclic guanosine monophosphate (cGMP) from guanosine 5 '-triphosphate (GTP). cGMP activating CGMP-dependent protein kinase (PKG) that leads to phosphorylate several proteins. These reactions reduce intracellular calcium levels and result in the relaxation of arterial and smooth muscles. https://doi.org/10.6084/m9.figshare.16863451.v1 
tone ${ }^{12-18}$. Nitric oxide (NO), the principal mediator of relaxation systems, is released from nonadrenergic/ noncholinergic (NANC) neurons and the endothelium. Two forms of NO synthase (NOS), nNOS and eNOS, are derived from the nervous system and endothelial cells, respectively. While nNOS is responsible for the initiation of corporal smooth muscle relaxation, eNOS drives the maintenance of smooth muscle relaxation and penile erection. Sexual stimulus provokes neural pathways, causing NO to be released straight into the penis. When NO interacts with guanylyl cyclase, the enzyme undergoes a conformational shift, resulting in the catalytic synthesis of 3'-5' cyclic guanosine monophosphate (cGMP) from guanosine 5' triphosphate. cGMP triggers penile erection by activating cGMP-dependent protein kinase $(\mathrm{PKG})$, which in turn phosphorylates several proteins. The cascade of reactions causes a decrease in intracellular calcium levels and the consequent relaxation of arterial and trabecular smooth muscle, leading to arterial dilatation, venous constriction, and the rigidity of penile erection. Phosphodiesterase type 5 inhibitors (PDE5i) impact this pathway $8,9,19,20$ (Figure 1 ).

Currently, several therapeutic approaches have demonstrated their efficacy and are recommended in guidelines, categorized into three lines of treatment (Figure 2): lifestyle modifications, oral medications with PDE5i, intracavernosal injection (ICI), vacuum device, and penile prosthesis implant ${ }^{10}$. Although the majority of ED patients can be treated with these medications and devices, approximately $20 \%$ of ED cases respond poorly to treatment ${ }^{22}$. Alternative therapies have been studied recently; low-intensity extracorporeal shock wave therapy (LiSWT) was also conditionally recommended in the recent guidelines of both the American Urological Association (AUA) and the European Association of Urology (EAU) ${ }^{11,23}$. Besides this, the AUA and Sexual Medicine Society of North America (SMSNA) have mentioned intracavernosal stem cell therapy (SCT) and autologous platelet-rich plasma (APRP) therapy, which are novel regenerative therapeutic approaches for the management of $\mathrm{ED}^{\mathbf{2 3 , 2 4}}$. However, these therapies continue to be investigational due to limited evidence.

Generally, regenerative therapeutics used for the treatment of ED and a significant number of other diseases are based on the concept of functional and structural restoration of damaged tissues and cells by replacement with or regeneration of new cells. Intracavernosal SCT and APRP therapy have gained attention in research, with both preclinical and clinical studies being conducted. Therefore, this article aims to review the current advances in these regenerative therapeutics for ED.

\section{APRP FOR THE TREATMENT OF ED}

Platelet-rich plasma (PRP) is an autologous product obtained from whole blood that contains around 1 million platelets $/ \mu \mathrm{L}$ in $5 \mathrm{~mL}$ of plasma ${ }^{26}$. Platelet releasates, which include adhesion proteins, angiogenic factors, chemokines, clotting factors and inhibitors, integral membrane proteins, immunological mediators, and other active molecules, play a fundamental role in homeostasis, tissue regeneration, vascularization, and wound healing. Growth factors within platelet $\alpha$-granules include platelet-derived growth factor (PDGF), insulin-like growth factor (IGF), vascular endothelial growth factor (VEGF), plateletderived angiogenic factor (PDAF), and transforming growth factor-beta (TGF- $\beta$ ) (Table 2$)^{27}$. Numerous substances such as thrombin, calcium chloride, or collagen can activate platelets, causing the release of these growth factors. Cryopreservation and freezedrying are excellent methods for storing PRP with a stable baseline level of growth factors and biological activities for long periods. Besides, as a plateletderived biomaterial, platelet-rich fibrin (PRF) produces a more solid-like gel structure with the fibrin network and was proven to be effective in some conditions ${ }^{28}$.

PRP is a product derived from hematology and was first applied in the 1970 s to concentrate platelets for transfusion to treat thrombocytopenia patients ${ }^{29}$. Ten years later, PRP began to be used in maxillofacial surgery as a PRF product. PRP's anti-inflammatory effects boosted cell proliferation, and fibrin had the potential for adhesion and homeostatic capabilities. In the musculoskeletal field, PRP therapy has mostly been used to treat sports injuries. As a result of its use in professional athletes, it has received substantial media attention and is widely used in this field. Other medical fields also utilize PRP therapy based on a variety of in vivo/in vitro studies, including cardiothoracic surgery, pediatric surgery, plastic surgery, neurosurgery, gynecology, urology, and ophthalmology. Lately, the use of PRP in dermatology has gained more interest due to its capacity for tissue restoration, wound healing, scar revision, skin rejuvenation, and alopecia treatment ${ }^{28}$.

Regarding urology, scientists have started to evaluate the effect of PRP on many clinical conditions such as $\mathrm{ED}$, stress urinary incontinence (SUI), and PD. The initial outcomes of this therapy indicated feasibility and safety. Matz et al. examined the efficacy and 


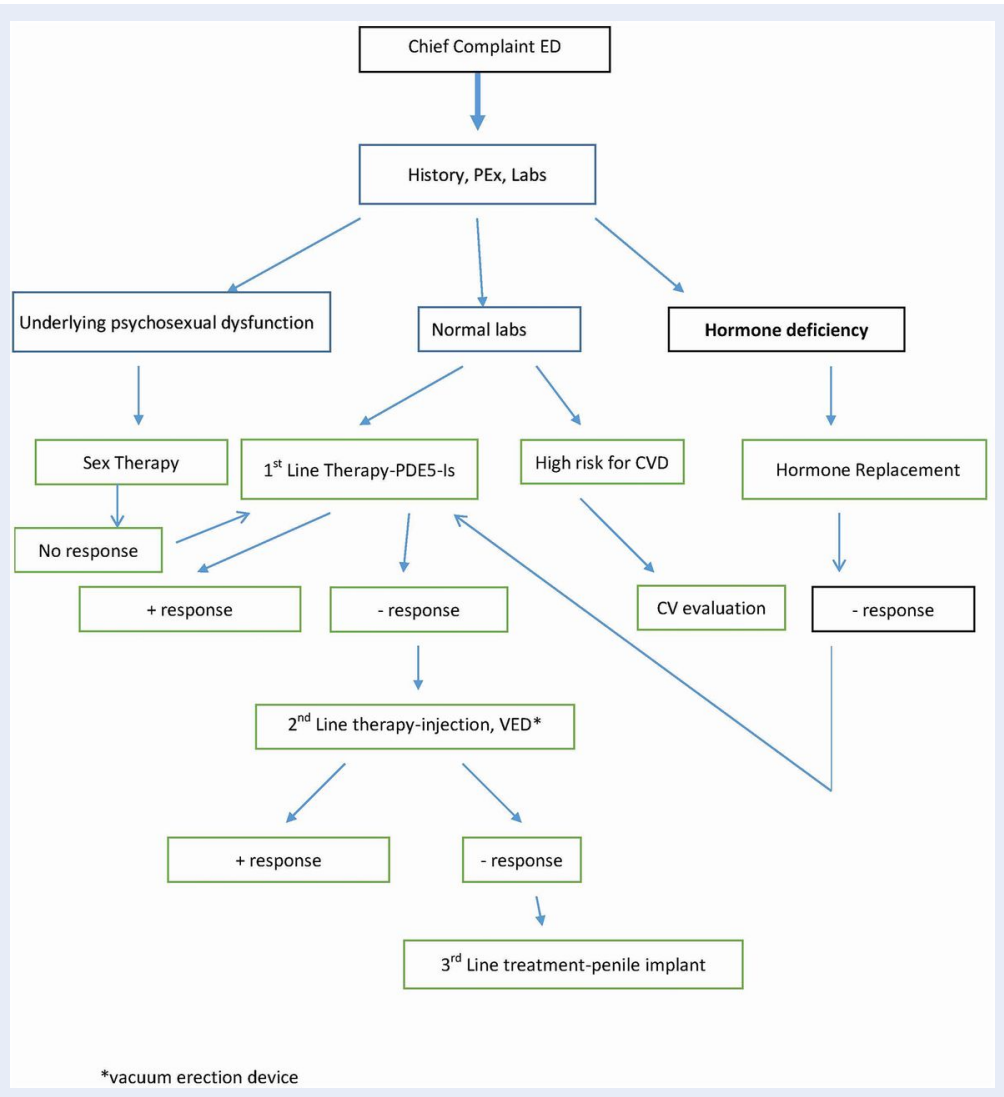

Figure 2: Algorithm of managing ED ${ }^{10}$. Patients with a chief complaint of ED are under-investigated medical history, physical examination (psychosexual factors and cardiovascular disease evaluation), and laboratory tests. The first-line therapy includes lifestyle modification, oral therapy with PDE5i, and testosterone supplementation if the hormone is deficient. Intraurethral or intracavernosal al prostadil and vacuum erection devices are considered as the second-line treatment if patients respond poorly to the first-line. The final treatment for refractory ED is penile prosthesis implantation — the third-line therapy.

PEx: Physical examinaton, CVD: coronary vascular disease. https://doi.org/10.6084/m9.figshare.16863454.v1

Table 2: Summary of the regenerative functions of some growth factors contained in APRP 21,25

\begin{tabular}{ll}
\hline APRP growth factor & \multicolumn{1}{c}{ Functions } \\
\hline $\begin{array}{l}\text { Vascular endothelial growth factor } \\
\text { (VEGF) }\end{array}$ & Angiogenesis, cell proliferation and migration of endothelial and stem cells \\
$\begin{array}{l}\text { Basic fibroblast growth factor (bFGF) } \\
\text { Mnsulin-like growth factor (IGF) }\end{array}$ & $\begin{array}{l}\text { Myonesis, VEGF system regulation, activation of endothelial cells prolifera- } \\
\text { tion, vessel maturation } \\
\text { Neurite growth, restoration of smooth muscle cells integrity; migration and pro- }\end{array}$ \\
$\begin{array}{l}\text { liferation of endothelial cell progenitors } \\
\text { (PDGF) }\end{array}$ & $\begin{array}{l}\text { Angiogenesis, proliferation and migration perivascular cells } \\
\text { Interleukins (IL): IL-2 and IL-8 }\end{array}$ \\
\hline
\end{tabular}




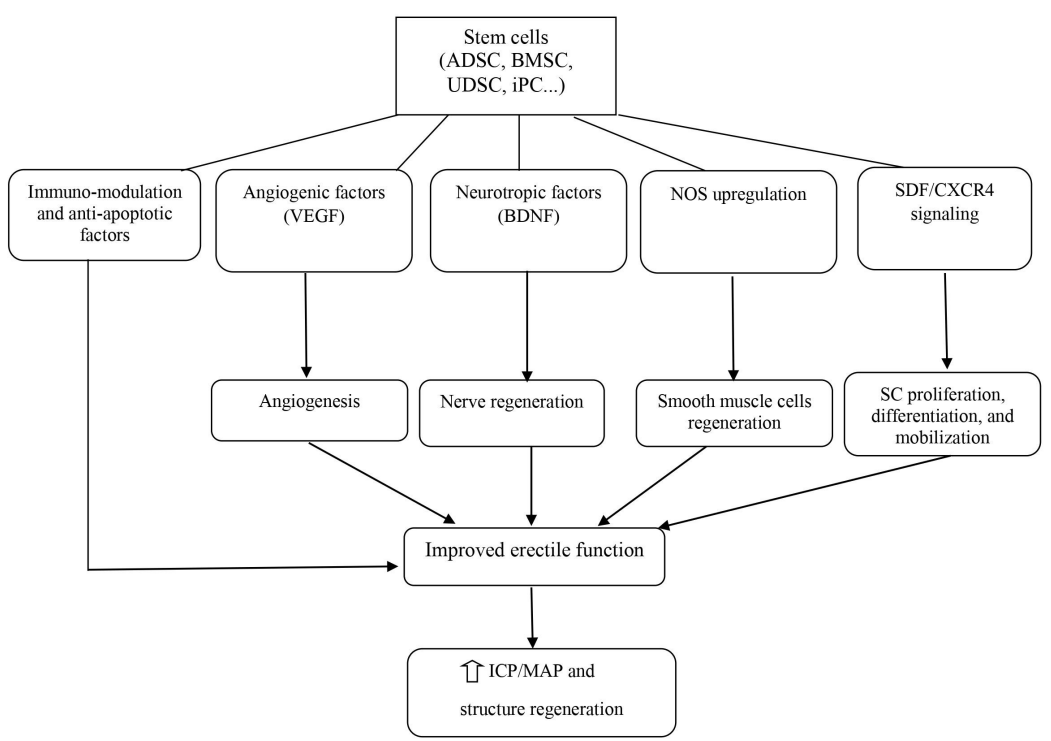

Figure 3: Mechanism of SCT for the treatment of ED ${ }^{21}$. Stem cells (SC) including adipose-derived stem cells (ADSC), bone marrow-derived stem cells (BMSC), urine-derived stem cells (UDSC), induced pluripotent stem cells (iPSC) were studied for the treatment of ED. These SC had immuno-modulatory and anti-apoptotic impact to repair and regenerate the injury of penile nerves or muscle. Growth factors enriched from SC such as vascular endothelial growth factor (VEGF) and brain-derived neurotrophic factor (BDNF) promoted angiogenesis and nerve fibes regeneration. The upregulation of NO synthetase effect reduced fibrosis and increased smooth muscle cells in corpus cavernosum. Regulating through stromal-cell derived factor (SDF)/CXCR4 chemokine receptor complex mediated pathway enhanced SC mobilization, proliferation and differentiation into nerves and endothelial cells. These effects improved even penile structure and function (increase mean maximal intracavernosal pressure/mean arterial pressure — ICP/MAP). https://doi.org/10.6084/m9.figshare.16863457.v1

safety of PRP therapy in the form of a platelet-rich fibrin matrix product in 17 patients with ED, PD, ED + PD, or SUI. Four men with ED were given ICI, 11 underwent injection directly in PD plaques under ultrasound guidance, and one female with SUI was submucosally injected through cystoscopy. No major adverse events were reported. While efficacy was observed, including a reduction in subjective curvature in four out of five men with PD and a minor improvement in the ED questionnaire, the sample was too small to enable meaningful statistical analysis or conclusions $^{\mathbf{3 0}}$. For SUI, Nikolopoulos et al. hypothesized that the biological "adhesive, healing and hemostatic" effects of PRP might resolve the pubourethral ligament defects that lead to SUI. Several pilot studies trialed the local injection of autologous PRP for treating SUI, injecting into the anterior vaginal mucosa around the patient's mid-urethra or the external sphincter. The findings revealed a satisfactory response post treatment, with improvements in symptom scores and urodynamic parameters as well as bladder function post treatment ${ }^{31}$.
For the treatment of PD, an acquired penile disorder characterized by benign changes primarily to the tunica albuginea, a single study recently reported robust evidence, using a combination of APRP and hyaluronic acid for the treatment of 90 patients with PD. Both penile deformation and the thickening of the tunica albuginea significantly decreased after four treatment sessions with the combination of PRP and hyaluronic acid injection into the tunica albuginea. The authors strongly recommended this fully natural treatment as a first-line treatment for $\mathrm{PD}^{32}$. Meanwhile, there is substantial evidence demonstrating the link between PD and ED.

The most robust data from the ED literature comes from research using animal models ${ }^{27}$. Studies were performed in rodents with ED-associated diabetes mellitus, bilateral $\mathrm{CN}$ injury, and hyperlipidemia. Emerging evidence suggests that neuropilin ligands and growth factors, such as insulin growth factor1 (IGF-1), PDGF, and VEGF have a positive effect on neural regeneration and the upregulation of neuronal NO synthetase as well as the recovery of erectile function after $\mathrm{CN}$ injury ${ }^{33-36}$. A study showed 
that the high level of PDGF in PRP aided the recovery of erectile function when injected directly into the corpus cavernosum of a rat with bilateral cavernous injury. Moreover, the concentration gradients of TGF and PDGF primarily elevated the process of wound healing and induced the release of other growth factors as well as the production of extracellular matrix. Collagen synthesis, angiogenesis, chemotaxis, and collagen breakdown protection were all boosted by PDGF and TGF, resulting in tissue regeneration. Ingman et al. suggested that a TGF beta 1 null mutation may induce ED through its role in altering the structural integrity of the penile skin and impairing tissue. IGF-1 enhances neurite outgrowth and VEGF promotes angiogenesis, which could be the mechanism underlying the effect of PRP in the treatment of ED. Scientists reported that the animal group with CN injury treated with PRP had a significant improvement in mean maximal intracavernosal pressure (ICP) and maximal ICP/mean arterial pressure (MAP) compared with the controls. In terms of the histology of penile tissue, more myelinated axons in the $\mathrm{CN}$ and more nicotinamide adenine dinucleotide phosphate-positive nerve fibers were seen in the group that received PRP injection ${ }^{36}$.

Despite good evidence regarding PRP therapy in animal models, sample sizes are limited and it is acknowledged that clinical effects may vary depending on dose, preparation method, and administration ${ }^{37}$. A clinical study investigated the action of growth factors in APRP used for ED treatment and revealed that the mechanism of erectile function recovery is based on the active substances in APRP, i.e., FGF-basic, PDF-AA, PDF-BB, VEGF, VEGF-D, and FGF-acid ${ }^{38}$. Another study found that PRF matrix (PRFM) injection is well-tolerated and feasible for the treatment of common urologic conditions including ED, PD, and $\mathrm{SUI}^{30}$. The results showed an improvement in the International Index of Erectile Function (IIEF) score of an average of 4.14 points after PRFM injection. Ruffo et al. reported that the patient group treated with a combination of LiSWT and autologous PRP for ED had improved IIEF scores and peak systolic velocity (PSV) of the cavernosal artery compared with the group treated with only LiSWT after 12 weeks of follow-up ${ }^{39}$. Another prospective study on treatment with intracavernous PRP in 31 patients reported a significant improvement in IIEF-Erectile Function domain values $(18$ vs. $20, \mathrm{p}<0.01)$ and sexual satisfaction scores $(6 v s .8, \mathrm{p}=0.02)$ compared with the previous procedure $^{40}$. The results of the first single-center, double-blind, randomized controlled trial evaluating the efficacy and safety of autologous PRP injection in patients with mild and moderate ED were recently published. Sixty sexually active patients were randomly divided into two groups. Group $1(\mathrm{n}=30)$ was assigned two sessions, 1 month apart, of $10 \mathrm{ml}$ PRP and Group $2(n=30)$ received placebo. At the 6-month follow-up, a higher number of patients in the group receiving PRP were satisfied compared with those receiving placebo. Additionally, the proportion of patients achieving the minimal clinically important difference in the IIEF-Erectile Function domain score from baseline was higher in the group treated with PRP than in the placebo group (69\% vs $27 \%$, p $<0.001)$. Furthermore, no significant adverse events were reported ${ }^{41}$. The positive initial outcomes of this trial revealed the scientific foundation of the application of PRP for ED; nonetheless, these findings are based on only a single center with a specific PRP separation system. Therefore, it is crucial to design multicenter studies with a large number of samples to adequately demonstrate the efficacy of PRP therapy for ED.

Numerous factors contribute to the pathophysiology of ED, and a significant proportion of cases results from endothelial dysfunction secondary to inflammation ${ }^{42}$. Thus, the most common mechanism underlying ED treatments aims to improve endothelial function through the augmentation of the NO pathway $^{43}$. The target of PRP therapy is to regulate the inflammatory response and promote tissue regeneration. Of note, it has been acknowledged that the biological properties of PRP may vary depending on dose, preparation method, and administration.

Although APRP is not FDA-approved, it can be legally used off-label by clinics in the USA for musculoskeletal indications as well as other indications including ED. Currently, a variety of commercial products are available for PRP separation, such as JP200 (BS Medical Co, South Korea), GLO PRP (Glofinn America LLC, USA), Magellan Autologous Platelet Separator System (Isto Biologics, USA), and SELPHYL (Factor Medical LLC, USA). These commercialized PRP therapies are marketed as the Priapus shot or "P-shot" and are widely used for the treatment of ED by numerous clinics worldwide. The treatment of ED with APRP is currently registered with the US Patent and Trademark Office as a "service mark", delineating a specific protocol for application in this setting. According to Scott et al., PRP therapy is already in use in 19 countries, with 683 providers. Despite limited clinical evidence, numerous clinicians worldwide have advertised the dramatic effects of PRP therapy in improving erectile function via social media and web-based platforms for commercial purposes; however, these cannot be considered trustworthy sources ${ }^{37}$. 
Table 3: Summary of clinical trials of SCT for ED

\begin{tabular}{|c|c|c|c|c|c|}
\hline Study & $\begin{array}{l}\text { Population } \\
\text { (n) }\end{array}$ & Source & $\begin{array}{l}\text { Time of } \\
\text { follow-up }\end{array}$ & Type of study & Outcomes \\
\hline Bahk et al. $(2010)^{44}$ & $\begin{array}{l}\text { Type } 2 \text { DM } \\
(\mathrm{n}=7)\end{array}$ & $\begin{array}{l}\text { Umbillical cord-derived } \\
\text { SC }\end{array}$ & $9 \mathrm{mo}$ & $\begin{array}{l}\text { Phase I single- } \\
\text { blind study }\end{array}$ & $\begin{array}{l}6 / 7 \text { morning erection by the } 3 \text { mo and maintained for more than } 6 \\
\text { mo }\end{array}$ \\
\hline Haahr et al. (2016) ${ }^{45}$ & $\begin{array}{l}\text { Post-RP } \\
(\mathrm{n}=17)\end{array}$ & $\begin{array}{l}\text { Adipose-derived } \\
\text { regenerate cells }\end{array}$ & $6 \mathrm{mo}$ & $\begin{array}{l}\text { Open-Label } \\
\text { Phase I, single- } \\
\text { arm study }\end{array}$ & $\begin{array}{l}\text { Well-tolerated, minor adverse events } \\
8 / 17 \text { recovered erectile function } \\
8 / 11 \text { continent men recovered erectile function } \\
\text { Median IIEF- } 5 \text { score increased ( } 7 \text { to } 17 \text { ) }\end{array}$ \\
\hline Haahr et al. (2018) ${ }^{46}$ & $\begin{array}{l}\text { Post-RP } \\
(\mathrm{n}=21)\end{array}$ & $\begin{array}{l}\text { Adipose-derived } \\
\text { regenerate cells }\end{array}$ & $12 \mathrm{mo}$ & $\begin{array}{l}\text { Open-Label } \\
\text { Phase I, single- } \\
\text { arm study }\end{array}$ & $\begin{array}{l}\text { No serious adverse events } \\
8 / 15 \text { continent patients ( } 53 \% \text { ) improved erectile function } \\
\text { No improvements in incontinent group }\end{array}$ \\
\hline $\begin{array}{l}\text { Levy et al. } \\
(2016)^{47}\end{array}$ & $\begin{array}{l}\text { Non-responders to } \\
\text { PDE5I } \\
(\mathrm{n}=8)\end{array}$ & Placental-derived SC & $6 \mathrm{mo}$ & Phase I/II & $\begin{array}{l}\text { Increase in PSV after } 3 \text { mo, } 6 \text { mo } \\
\text { No change in EDV, stretched penile length, penile width, and IIEF } \\
\text { scores }\end{array}$ \\
\hline Yiou et al. (2016) ${ }^{48}$ & $\begin{array}{l}\text { Vasculogenic post- } \\
\text { RP ED } \\
(\mathrm{n}=12)\end{array}$ & BM-MSC & $12 \mathrm{mo}$ & Phase I/II & $\begin{array}{l}\text { No serious side effects } \\
6 \mathrm{mo} \text { : improve intercourse satisfaction, erectile function, domains } \\
\text { of the IIEF-15 and Erection Hardness Scale (EHS) } \\
\text { Improve PSV and \% NO release test and sustained after } 1 \mathrm{yr}\end{array}$ \\
\hline Yiou et al. (2017) ${ }^{49}$ & $\begin{array}{l}\text { Post-RP } \\
(\mathrm{n}=18)\end{array}$ & BM-MSC & $\begin{array}{l}\text { Mean } 62.1 \\
\text { mo }\end{array}$ & Phase I/II & $\begin{array}{l}\text { No serious side effects } \\
6 \mathrm{mo} \text { : improve IIEF-15 intercourse satisfaction vs. baseline and } \\
\text { erectile function domains } \\
\text { Mean follow-up } 62.1 \mathrm{mo} \text { : erectile function scores were slightly } \\
\text { lower compared with the } 1 \text {-y time point }\end{array}$ \\
\hline Demour et al. $(2018)^{\mathbf{5 0}}$ & $\begin{array}{l}\text { Type } 2 \text { DM } \\
(\mathrm{n}=4)\end{array}$ & BM-MSC & $\begin{array}{l}\text { Safety } 24 \\
\text { mo } \\
\text { Efficacy: } 12 \\
\text { mo }\end{array}$ & $\begin{array}{l}\text { Phase I open } \\
\text { label }\end{array}$ & $\begin{array}{l}\text { No significant adverse effects } \\
\text { Improve IIEF-15 and EHS; erectile function, sexual desire, inter- } \\
\text { course satisfaction, and overall satisfaction }\end{array}$ \\
\hline
\end{tabular}

Continued on next page 


\begin{tabular}{|c|c|c|c|c|c|}
\hline \multicolumn{6}{|c|}{ Table 3 continued } \\
\hline Study & $\begin{array}{l}\text { Population } \\
\text { (n) }\end{array}$ & Source & $\begin{array}{l}\text { Time of } \\
\text { follow-up }\end{array}$ & Type of study & Outcomes \\
\hline You et al. (2019) & $\begin{array}{l}\text { Post RP }(\mathrm{n}=5) \\
\text { DM ascociated ED } \\
(\mathrm{n}=5)\end{array}$ & BM-MSC & $12 \mathrm{mo}$ & $\begin{array}{l}\text { Phase I open } \\
\text { label }\end{array}$ & $\begin{array}{l}\text { At } 30 \mathrm{~d} \text {, improve mean IIEF score post treatment } v s \text { baseline. Nc } \\
\text { severe adverse events associated the treatment }\end{array}$ \\
\hline $\begin{array}{l}\text { Protogerou et al. } \\
(2019)^{52}\end{array}$ & Organic $\operatorname{ED}(\mathrm{n}=8)$ & $\begin{array}{l}\text { Group A: ADSC and } \\
\text { Platelet Lysate Plasma } \\
\text { Group B: Platelet Lysate } \\
\text { Plasma alone }\end{array}$ & $3 \mathrm{mo}$ & $\begin{array}{l}\text { Phase I open } \\
\text { label, single } \\
\text { center,pilotstudy }\end{array}$ & $\begin{array}{l}\text { No severe adverse reactions } \\
\text { Improved erectile function } \\
\text { No significant difference between group A and B } \\
\text { All patients improved penile triplex and increased morning erec- } \\
\text { tions }\end{array}$ \\
\hline $\begin{array}{l}\text { Protogerou et al. } \\
(2020)^{53}\end{array}$ & $\begin{array}{l}\text { Organic ED } \\
(\mathrm{n}=5)\end{array}$ & $\begin{array}{l}\text { ADSC and Platelet } \\
\text { Lysate Plasma }\end{array}$ & $6 \mathrm{mo}$ & $\begin{array}{l}\text { Phase I single } \\
\text { center pilot study } \\
\text { PhaseI }\end{array}$ & $\begin{array}{l}\text { Improve IIEF- } 5 \text { scores, PSV in all patients, EDV was more variable } \\
\text { No side effects }\end{array}$ \\
\hline Bieri et al. $(2020)^{54}$ & $\begin{array}{l}\text { PDE5i- } \\
\text { unrespossive } \\
\text { ED } \\
(\mathrm{n}=40)\end{array}$ & BM-MSC (Caverstem) & $12 \mathrm{mo}$ & & $\begin{array}{l}\text { Minor adverse effects: short-term bruising } \\
\text { Improve IIEF scores in group receiving Caverstem } 1.0 \text { low dose } \\
\text { high dose and Caverstem } 2.0 \text { vs baseline that peaked by } 3 \text { mo anc } \\
\text { maintained at } 6 \text { mo } \\
\text { No change in doppler ultrasound and cavernosmetry }\end{array}$ \\
\hline
\end{tabular}

Abbreviations: ADSC: Adipose-derived stem cells, BM-MSC: Bone marrow-derived stem cells, d: day, DM: Diabetes, EDV: End Diastolic Velocity, EHS: Erection Hardness Scale, IIEF: the International Index of Erectile Function, Mo: month, PSV: Peak Systolic Velocity, RP: radical, y: year 
POTENTIAL OF SCT FOR IMPROVING PENILE ERECTILE FUNCTION

SCT was first applied in the 1990s and gradually became a prominent global research trend, being applied in numerous medical fields for the treatment of conditions such as hematologic disease, malignancies, cardiovascular disease, and neurologic disease due to its anti-inflammatory, restorative, and immunomodulatory effects ${ }^{55}$. Stem cells (SC) are pluripotent cells that can be derived from many sources within the body. These cells are capable of dividing and differentiating into any cell lineage ${ }^{56}$. Based on the source, SC can be classified into embryonic SC and adult SC; embryonic SC comprise the inner cells of a blastocyst and adult SC comprise diverse tissues of a developed or developing individual. Regarding differentiation potential, embryonic SC are pluripotent, while adult SC are multipotent. Adult SC can be classified into hematopoietic, neural, epithelial, and mesenchymal. Among these, mesenchymal SC are widely used in ED research. These SC types are capable of differentiating into mesenchymal tissues, such as bone, cartilage, and fat ${ }^{57}$. SCT has tremendous potential for a wide range of applications; tissue engineering with SC-based technology has also gained significant interest. SC can be utilized in regenerative medicine, immunotherapy, and gene therapy. Preclinical and clinical studies of SC transplantation have shown encouraging results regarding the treatment of various conditions such as immunohematologic disorders, type 1 diabetes mellitus, Parkinson's disease, and heart failure. Adult SC collection typically consists of at least three key stages: tissue biopsy to harvest the cells, ex vivo SC expansion, and SC delivery. The three different routes of SC administration are direct SC transplantation, transplantation of differentiated SC progeny, and tissue engineering ${ }^{58}$. In direct delivery, SC are introduced either locally or systemically into the body. SC delivery via regional injection results in their immediate distribution to the affected area and differentiation into the appropriate cell type. In contrast, SC homing technology is needed for the systemic delivery of SC. In spite of this, only $1 \%$ of SC administer through the intravenous route can actually immigrate to the target tissue. SC engraftment occurs through paracrine effects and the triggering of endogenous mechanisms of regeneration, enhancing the propagation and differentiation of progenitor cells that can promote the process of tissue recovery ${ }^{55}$. Besides, the immunomodulatory functions of SC can modulate a variety of target cells in the immune system $^{57}$.
The field of urology would also benefit from utilizing this therapeutic approach for several acute and chronic urologic conditions such as ED, PD, SUI, bladder underactivity, bladder outlet obstruction, and renal failure ${ }^{58}$. In particular, SCT with the development of tissue engineering has also been studied indepth for regenerating the components of the genitourinary system. Meanwhile, since ED is becoming a global public health problem, scientists have begun to focus on using SCT for this condition. In recent decades, SCT has progressed significantly, with a large number of preclinical studies as well as clinical trials in the field of ED. The emerging mechanism for ED treatment revolves around neuronal preservation and cytoprotection by the inhibition of cellular apoptosis $^{59}$. ICI of vasoactive agents was proven to be efficacious and safe; therefore, it is the most popular and appropriate route of SC delivery. SC delivery by injection to the major pelvic ganglia, periprostatic injection with or without intracorporal injection, and intravenous injection has also been attempted but is less feasible than ICI. SC regenerate penile tissue by producing growth factors locally via paracrine effects or immigration into the major pelvic ganglia; concurrently, SC can differentiate into smooth muscle, endothelium, and neuronal tissues (Figure 3). However, the precise mechanisms underlying $\mathrm{SC}$ effects in $\mathrm{ED}$ are not clear so far ${ }^{21,57}$.

In 2004, Bochinski et al. conducted a pioneering study on the use of SCT for the treatment of ED in rodent models. They used embryonic SC for this study, a very challenging task as establishing rat embryonic SC in culture is difficult. Their research findings revealed that out of the total of 26 male rats, the group that was administered an ICI of neural embryonic SC into the major pelvic ganglia and corpora cavernosa had significantly higher ICP than the control group. Observation of neurofilament staining and NOS-containing nerve fibers in this pioneering study also showed amelioration of neurogeneration or nerve preservation compared with controls ${ }^{60}$. Nonetheless, due to the obstacles in establishing cell cultures and ethical concerns regarding the use of embryos as a source of SC as well as the emergence of mesenchymal SC, other sources of SC have been used to demonstrate the efficacy and safety of this therapy in preclinical and even clinical studies of ED. These sources include adipose tissue-derived SC (ADSC), bone marrow-derived SC and induced pluripotent SC (iPSC).

ADSC are the most widely used SC type in ED research given that they are easy to obtain from abundant tissue sources ${ }^{\mathbf{6 1}}$. ADSC can be harvested 
through surgery and direct excision, liposuction in the trunk and extremities as well as the Coleman technique for fat tissue transplantation and remodeling. Therefore, these SC types have more advantages in terms of harvest, isolation, and expansion. Studies have been conducted in animal models with ED induced by several conditions such as diabetes, $\mathrm{CN}$ injury, and pelvic irradiation. Most studies utilized ADSCs alone or in combination with other cells or growth factors. The results demonstrated improvements in erectile function after ICI with ADSC by increasing smooth muscle, collagen, and endothelial as well as NOS level in the dorsal penile nerve ${ }^{21}$. Hou et al. conducted a meta-analysis of ADSC injection for ED in rats. The 20 studies analyzed included a total of 428 rats with ED associated with diabetes mellitus, $\mathrm{CN}$ injury, tunica albuginea injury, radiation, or cigarette smoke. The results showed that ADSC therapy aided the recovery of erectile function and regenerated cavernous structures in ED rats. These effects were indicated by a considerable increase in the ratio of ICP and MAP, levels of nNOS, cavernous smooth muscle content (CSMC), the ratio of CSMC and collagen, and the cGMP level following ADSC therapy compared with control therapy. Subgroup analysis revealed that ADSC modified by growth factors or neurotrophic factors significantly improved erectile function compared with ADSC therapy alone $(p<0.001)$. Furthermore, observation of substantial amelioration in erectile function was reported in the subjects with more cell transplantation. This study showed that there was no statistically meaningful difference when analyzing the sources of ADSC, methods of transplantation, and the cause of $\mathrm{ED}^{62}$.

Bone marrow-derived mesenchymal SC (BM-MSC) are a type of pluripotent $\mathrm{SC}$ from the mesoderm that can be another valuable source for developing regenerative therapies ${ }^{21}$. BM-MSC can be isolated from the mononuclear fraction harvested by bone marrow aspiration. Studies on ICI with BM-MSC in diabetic animals showed good results in terms of increased content of endothelium and smooth muscle in the corpus cavernosum and increased expression of the neural marker nNOS and neurofilament in the dorsal nerve. Cavernosal tissue with BM-MSC transplantation was observed to differentiate into endothelial and smooth muscle-like cells in the corpus cavernosum in a diabetes-induced ED rat model. Bivalacqua et al. reported that BM-MSC persisted in the corporal tissue for at least 21 days and did not trigger a noticeable inflammatory reaction based on histological examination. BM-MSC have been shown to improve erectile function in aged rats ${ }^{63}$. Chen et al. compared the therapeutic effects of ADCS and BM-MSC in a diabetic ED rat model. The authors found that the group with ADSC injection showed a more effective recovery of erectile function than the group with BM-MSC injection. They observed higher ICP and ICP/MAP ratios and improvements in the expression of eNOS in the penile tissue of the group with ADSC injection; additionally, histological analysis showed that ADSC treatment promoted revascularization of the corpus cavernosum and reduced penile collagen compared with the untreated group ${ }^{64}$.

Other sources of SC such as iPSC, skeletal musclederived SC (SM-DSC), fetal brain SC, endothelial progenitor cells (EPC), and Wharton's jelly-derived SC have also been studied for the treatment of ED, with encouraging outcomes. According to reports, ICI of these SC types in a $\mathrm{CN}$ injury rat model enhanced smooth muscle, ICP, and eNOS content, leading to erectile function recovery ${ }^{21}$.

Additionally, certain studies on SC modification have been conducted wherein SC were transduced or transfected with genes known to encode proteins positively correlated with normal erectile function. Significant benefits were only demonstrated through preclinical data; thus, there is no clinical data on the implementation of transfected or transduced SC. These approaches include non-hematopoietic adult bone marrow stem/progenitor cells isolated by $\mathrm{p} 75 \mathrm{NGF}$ receptor (p75dMSCs) used in rats with $\mathrm{CN}$ injury, $\mathrm{AD}$ SCs and nerve growth factor (NGF)-incorporated hyaluronic acid-based hydrogels, and ADSCs and autologous vein grafts, and the results showed that the SC modification was more effective compared with typical SCT ${ }^{65}$.

In terms of clinical studies, we searched the United States National Institute of Health and Pubmed database using the search teams "stem cell" and "erectile dysfunction" and found several small trials evaluating the efficacy and safety of SCT in patients with $\mathrm{ED}^{\mathbf{6 6}}$. ICI was utilized to directly deliver SC in all studies. SC were obtained from a variety of sources (umbilical cord SC, BM-DMSC, placental-derived SC, and ADSC), produced by different methods, and given at different dosages. The research subjects were typically patients with type 2 diabetes mellitusassociated ED, post RP ED, or PDE5i-unresponsive ED. All studies reported no serious side effects and revealed significant improvements in questionnaire scores (IIEF and Erection Hardness Score [EHS]) and penile hemodynamics (PSV and end-diastolic velocity [EDV]) via ultrasound. Furthermore, no serious complications associated with the SCT were recorded (Table 3). 
In 2010, Bahk et al. reported the efficacy of a single ICI of allogeneic human umbilical cord blood SC (UCB-SC) in seven diabetic patients with ED. After SC infusion $\left(1.5 \times 10^{7}\right.$ cells $)$, improvements were seen in penile hemodynamic parameters, libido, and the decrease of serum glucose without immune suppression. No significant adverse effects were observed. Haahr et al. conducted phase I trials to evaluate the effect of a single-dose ICI of adipose-derived regenerative cells (ADRC) in ED patients after RP at 6 and 12 months of follow-up. In both studies, improvements in IIEF- 5 scores were seen among continent men, but no changes were observed among incontinent men. Additionally, minor complications related to liposuction and cell injections were reported.

In 2016, another phase I trial was performed in eight patients with PDE5i-unresponsive ED who were treated with a single ICI of placental-derived SC. Three out of eight patients experienced irritation at the injection site that resolved after 48 hours. No patient went on to develop other serious adverse events. At the 6-week follow-up, PSV ranged from $25.5 \mathrm{~cm} / \mathrm{s}$ to $56.5 \mathrm{~cm} / \mathrm{s}$; at 3 months, PSV ranged from $32.5 \mathrm{~cm} / \mathrm{s}$ to $66.7 \mathrm{~cm} / \mathrm{s}$. The increase in PSV was statistically significant $(\mathrm{p}<0.01)^{44}$.

Yiou et al. performed phase I and II studies to trial BM-MSC for the treatment of post-RP ED (INSTIN: IntraCavernous Stem-Cell Injection clinical trial). Theirs is the first phase II clinical trial of SCT for ED. In the first phase, autologous BM-MSC were administered by a single ICI in four escalating doses $\left(2 \times 10^{7}, 2 \times 10^{8}, 1 \times 10^{9}\right.$, and $2 \times 10^{9}$ cells $)$ to 12 ED patients. There were no significant adverse effects after 6 months. The results showed improvements in the Intercourse Pleasure $(6.8 \pm 3.6,3.9 \pm 2.5, \mathrm{p}<$ $0.05)$ and Erectile Function domains $(17.2 \pm 8.9,7.3$ $\pm 4.5, \mathrm{p}<0.05)$ of IIEF-15 as well as the EHS $(2.6 \pm$ $1.1,1.3 \pm 0.8, \mathrm{p}<0.05)$. Clinical benefits were associated with improvements in PSV and the \% penile NO release test and maintained at 1 year of follow-up. The higher doses significantly improved spontaneous erection. Subsequently, six patients were additionally recruited in the phase II trial and received a single injected dose of $1 \times 10^{9} \mathrm{BM}$-MSC. No side effects were recorded and erectile function recovered in a manner similar to trial stage I. Following a mean follow-up of $62.1 \pm 11.7$ months, IIEF scores decreased compared with the 1-year time frame. The authors suggested a need for repeat injections to optimize or maintain the treatment effects over time $\mathbf{4 8 , 4 9}^{\text {. }}$

Additionally, Al Demour et al. studied the effect of BM-MSC in four diabetes mellitus patients with refractory ED. Two consecutive intracavernous autolo- gous BM-MSC injections were administered at baseline and 30 days later. After a follow-up of 12 months for efficacy and 24 months for safety, none of the patients experienced significant adverse events. The results showed considerable improvements in IIEF-15 and EHS scores: IIEF-15 ( $p=0.04)$, Erectile Function ( $p=0.03)$, Sexual Desire $(p=0.04)$, Intercourse Satisfaction $(\mathrm{p}=0.04)$, and Overall Satisfaction $(\mathrm{p}=$ $0.04)^{50}$

In 2019, You et al. conducted a phase I clinical trial to assess the effects of autologous BM-MSC for the treatment of 10 patients with PDE5i-refractory ED (five post RP and five with diabetes mellitus). No clinical significance was reported that related to the treatment. IIEF scores increased significantly at 30 days of follow-up compared to baseline (24.9 vs. 18.1, p = $0.0222)^{51}$.

Protogerou et al. trialed the combination of ADSC and platelet lysate (PLP) to treat men with organic ED in a phase I study in 2019. Eight men were enrolled and divided into two groups. Five patients in Group A received $38.9 \pm 14.4 \times 10^{6}$ ADSC in combination with $2.2 \pm 0.3 \mathrm{~mL}$ of PLP, while three patients in Group B received $2.3 \pm 0.4 \mathrm{~mL}$ PLP alone. After 1 and 3 months of follow-up, erectile function had recovered following the application of the above treatments. Results showed a statistically significant difference in the IIEF-5 score before and after the treatments at the first month $(\mathrm{p}<0.05)$ and the third month $(\mathrm{p}<$ $0.05)$. However, there were no statistically significant differences in the IIEF- 5 score between groups. All patients recorded an improvement of penile triplex and morning erection. No severe adverse reactions were observed in any patient except minor pain at the site of injection. In 2020, the authors conducted another trial using the combination of ADSC and PLP in ED patients. The participants were separated into three groups (five men per group) treated with SC and PLP (Group A), SC only (Group B), and PLP only (Group C). Partial study results regarding Group A at 6 months post treatment were published. Five men had recovered erectile function with the amelioration of IIEF-5 scores and PSV, while EDV had a more variable pattern ${ }^{\mathbf{5 3}}$.

Remarkably, Bieri et al. recently conducted a phase I and registry study to assess autologous BM-MSC in PDE5i-refractory ED patients. A total of 40 men were enrolled in the clinical trial and given ICI of the concentrate from bone marrow aspiration (CaverStem $1.0 ; 30 \mathrm{~mL}$ and $60 \mathrm{~mL}$ bone marrow were concentrated into $3 \mathrm{~mL}$ for the low dose and $6 \mathrm{~mL}$ for the high 
dose, respectively); additionally, 100 men in the clinical registry were treated by ICI of $20 \mathrm{~mL}$ bone marrow aspirate (CaverStem 2.0). There was an improvement in the IIEF-5 scores in all three groups (CaverStem 1.0 low dose and high dose and CaverStem 2.0). The improvement peaked at 3 months and was maintained at 6 months of follow-up. No significant differences were observed via Doppler ultrasound and cavernosometry in the low-dose or high-dose groups. No serious adverse events were noted ${ }^{54}$.

\section{CONCLUSIONS AND FUTURE PERSPECTIVES}

Currently, there are several therapeutic approaches for ED, including both non-surgical and surgical treatments such as PDE5i, ICI therapy of vasoactive substances, vacuum erection devices, and penile prosthesis implants; however, each treatment has associated benefits and risks/burdens, not to mention the high proportion of men with ED who are unresponsive to or dissatisfied with these typical treatments, particularly patients with diabetes mellitus and $\mathrm{CN}$ injury. Thus, recovery of erectile function in these patients is still a challenge. Recent advances in our knowledge of ED have led to progress in the development of regenerative therapeutics that are proposed to be highly efficacious and long-lasting treatment options due to their capacity to restore penile tissue and $\mathrm{CN}$. Both SCT and APRP therapy have been proven to considerably improve penile erectile function in numerous animal models, with only a small number of clinical trials carried out thus far. Therefore, several guidelines worldwide recommend these therapies, albeit with caution. We still have a long way to go in demonstrating the feasibility and safety of these regenerative therapeutics in ED patients with extensive, multicenter, randomized, controlled clinical studies.

\section{ABBREVIATIONS}

APRP (PRP): Autologous platelet-rich plasma

AUA: American Urology Association

CNs: Cavernosal nerves

EAU: European Association of Urology

ED: Erectile Dysfunction

EDV: End diastolic velocity

FDA: Food and Drug Administration

ICI: Intracavernosal injection

IIEF: The International Index of erectile function

NOS: Nitric Oxide Synthetase

PD: Peyronie's Disease

PDE5I: Phosphodiesterase 5 inhibitors
PSV: Peak systolic velocity

RP: Radical prostectomy

SCT: Stem cell therapy

SMSNA: Sexual Medicine Society of North America

SUI: Stress urinary incontinence

\section{ACKNOWLEDGMENTS}

None.

\section{AUTHOR'S CONTRIBUTIONS}

Truong MH and Phan NK conceived the ideas and design study. Ngo TQ and Truong MH participated in collecting data and drafting the article. Phan NK was involved in the revision of the article. All authors read and approved the final manuscript.

\section{FUNDING}

None.

\section{AVAILABILITY OF DATA AND MATERIALS}

Not applicable.

\section{ETHICS APPROVAL AND CONSENT TO PARTICIPATE}

Not applicable.

\section{CONSENT FOR PUBLICATION}

Not applicable.

\section{COMPETING INTERESTS}

The authors declare that they have no competing interests.

\section{REFERENCES}

1. Montorsi F, Adaikan G, Becher E, Giuliano F, Khoury S, Lue TF. Summary of the recommendations on sexual dysfunctions in men. J Sex Med. 2010;7(11):3572-88. PMID: 21040491. Available from: 10.1111/j.1743-6109.2010.02062.x.

2. Ayta IA, McKinlay JB, Krane RJ. The likely worldwide increase in erectile dysfunction between 1995 and 2025 and some possible policy consequences. BJU Int. 1999;84(1):50-6. PMID: 10444124. Available from: 10.1046/j.1464-410x.1999.00142.x.

3. Feldman HA, Goldstein I, Hatzichristou DG, Krane RJ, McKinlay JB. Impotence and its medical and psychosocial correlates: results of the Massachusetts Male Aging Study. J Urol. 1994;151(1):54-61. PMID: 8254833. Available from: 10.1016/ S0022-5347(17)34871-1.

4. Johannes $C B$, Araujo $A B$, Feldman $H A$, Derby $C A$, Kleinman $K P$, McKinlay JB. Incidence of erectile dysfunction in men 40 to 69 years old: longitudinal results from the Massachusetts male aging study. J Urol. 2000;163(2):460-3. PMID: 10647654. Available from: 10.1016/S0022-5347(05)67900-1.

5. Lewis RW, Fugl-Meyer KS, Bosch R, Fugl-Meyer AR, Laumann EO, Lizza E. Epidemiology/risk factors of sexual dysfunction. J Sex Med. 2004;1(1):35-9. PMID: 16422981. Available from: 10.1111/j.1743-6109.2004.10106.x. 
6. VoTV, Hoang HD, Nguyen NPT. Prevalence and associated factors of erectile dysfunction among married men in Vietnam. Front Public Health. 2017;5:94. PMID: 28523265. Available from: 10.3389/fpubh.2017.00094.

7. Leung AC, Christ GJ, Melman A. Physiology of penile erection and pathophysiology of erectile dysfunction. Atlas of Male Sexual Dysfunction. 2004:1-25. Available from: 10.1007/9781-4613-1087-7_1.

8. Corbin JD. Mechanisms of action of PDE5 inhibition in erectile dysfunction. Int J Impot Res. 2004;16(1):4-7. PMID: 15224127. Available from: 10.1038/sj.ijir.3901205.

9. Alan WS, L TF. Physiology of Penile Erection and Pathophysiology of Erectile Dysfunction. In: Alan W.Partin, Roger R.Dmochowski, Louis R.Kavoussi, Crage A.Peters, editors. Campbell-Walsh-Wein Urology. 12th editon. Canada: Elviser; 2020. p. 1485-512.

10. Mobley DF, Khera M, Baum N. Recent advances in the treatment of erectile dysfunction. Postgrad Med J. 2017;93(1105):679-85. PMID: 28751439. Available from: 10.1136/postgradmedj-2016-134073.

11. Salonia A, Bettochi C, Carvalho J, Corona G, Jones TH, Kadioğlu $A$, et al.. EAU guidelines on sexual and reproductive health 2020. European Association of Urology Guidelines. 2020.

12. Reed-Maldonado AB, Lue TF. The current status of stem-cell therapy in erectile dysfunction: a review. World J Mens Health. 2016;34(3):155-64. PMID: 28053944. Available from: 10.5534/ wjmh.2016.34.3.155.

13. Lue TF. Erectile dysfunction. N Engl J Med. 2000;342(24):1802-13. PMID: 10853004. Available from: 10.1056/NEJM200006153422407.

14. Prieto $D$. Physiological regulation of penile arteries and veins. Int J Impot Res. 2008;20(1):17-29. PMID: 17637789. Available from: 10.1038/sj.ijir.3901581.

15. Mulhall JP, Bella AJ, Briganti A, McCullough A, Brock G. Erectile function rehabilitation in the radical prostatectomy patient. J Sex Med. 2010;7(4 Pt 2):1687-98. PMID: 20388165. Available from: 10.1111/j.1743-6109.2010.01804.x.

16. Lin CS, Xin ZC, Wang Z, Deng C, Huang YC, Lin G. Stem cell therapy for erectile dysfunction: a critical review. Stem Cells Dev. 2012;21(3):343-51. PMID: 21793654. Available from: 10. $1089 / \mathrm{scd} .2011 .0303$.

17. lacono F, Giannella R, Somma P, Manno G, Fusco F, Mirone V. Histological alterations in cavernous tissue after radical prostatectomy. J Urol. 2005;173(5):1673-6. PMID: 15821546. Available from: 10.1097/01.ju.0000154356.76027.4f.

18. Fode $M$, OhI DA, Ralph D, S $\varnothing$ nksen J. Penile rehabilitation after radical prostatectomy: what the evidence really says. BJU Int. 2013;112(7):998-1008. PMID: 23826962. Available from: 10. 1111/bju.12228.

19. de Tejada IS, Angulo J, Cellek S, González-Cadavid N, Heaton J, Pickard R. Physiology of erectile function. J Sex Med. 2004;1(3):254-65. PMID: 16422955. Available from: 10.1111/j. 1743-6109.04038.x.

20. Kalsi J, Muneer A. Erectile dysfunction - an update of current practice and future strategies. J Clin Urol. 2013;6(4):210-9. PMID: 26097710. Available from: 10.1177/2051415813491862.

21. Liu MC, Chang ML, Wang YC, Chen WH, Wu CC, Yeh SD. Revisiting the Regenerative Therapeutic Advances Towards Erectile Dysfunction. Cells. 2020;9(5):1250. PMID: 32438565. Available from: $10.3390 /$ cells 9051250 .

22. Melman A, Davies K. Gene therapy for erectile dysfunction: what is the future? Curr Urol Rep. 2010;11(6):421-6. PMID: 20838943. Available from: 10.1007/s11934-010-0145-1.

23. Burnett AL, Nehra A, Breau RH, Culkin DJ, Faraday MM, Hakim LS, et al. Erectile Dysfunction: AUA Guideline . J Urol. 2018;200(3):633-641. PMID: 29746858. Available from: 10. 1016/j.juro.2018.05.004.

24. Liu JL, Chu KY, Gabrielson AT, Wang R, Trost L, Broderick G, et al. Restorative Therapies for Erectile Dysfunction: Position Statement From the Sexual Medicine Society of North America (SMSNA). Sex Med. 2020;9(3):100343. PMID: 34000480 Available from: 10.1016/j.esxm.2021.100343.
25. Epifanova MV, Gvasalia BR, Durashov MA, Artemenko SA. Platelet-rich plasma therapy for male sexual dysfunction: myth or Reality? Sex Med Rev. 2020;8(1):106-13. PMID: 30898594. Available from: 10.1016/j.sxmr.2019.02.002.

26. Marx RE. Platelet-rich plasma (PRP): what is PRP and what is not PRP? Implant Dent. 2001;10(4):225-8. PMID: 11813662. Available from: 10.1097/00008505-200110000-00002.

27. Matz EL, Scarberry K, Terlecki R. Platelet-Rich Plasma and Cellular Therapies for Sexual Medicine and Beyond. Sex Med Rev. 2020;p. In press. PMID: 32800771. Available from: 10.1016/j. sxmr.2020.07.001.

28. Alves R, Grimalt R. A review of platelet-rich plasma: history, biology, mechanism of action, and classification. Skin Appendage Disord. 2018;4(1):18-24. PMID: 29457008. Available from: 10.1159/000477353.

29. Andia I, Abate M. Platelet-rich plasma: underlying biology and clinical correlates. Regen Med. 2013;8(5):645-58. PMID: 23998756. Available from: $10.2217 / \mathrm{rme} .13 .59$.

30. Matz EL, Pearlman AM, Terlecki RP. Safety and feasibility of platelet rich fibrin matrix injections for treatment of common urologic conditions. Investig Clin Urol. 2018;59(1):61-5. PMID: 29333517. Available from: 10.4111/icu.2018.59.1.61.

31. Nikolopoulos KI, Pergialiotis V, Perrea D, Doumouchtsis SK. Restoration of the pubourethral ligament with platelet rich plasma for the treatment of stress urinary incontinence. Med Hypotheses. 2016;90:29-31. PMID: 27063081. Available from: 10.1016/j.mehy.2016.02.019.

32. Virag R, Sussman H, Lambion S, de Fourmestraux V. Evaluation of the benefit of using a combination of autologous platelet rich-plasma and hyaluronic acid for the treatment of Peyronie's disease. Sex Health. 2017;2017:1.

33. Wu YN, Wu CC, Sheu MT, Chen KC, Ho HO, Chiang HS. Optimization of platelet-rich plasma and its effects on the recovery of erectile function after bilateral cavernous nerve injury in a rat model. J Tissue Eng Regen Med. 2016;10(10):294-304. PMID: 23950105. Available from: 10.1002/term.1806.

34. Huang YC, Wu CT, Chen MF, Kuo YH, Li JM, Shi CS. Intracavernous Injection of Autologous Platelet-Rich Plasma Ameliorates Hyperlipidemia-Associated Erectile Dysfunction in a Rat Model. Sex Med. 2021;9(2):100317. PMID: 33529811. Available from: 10.1016/j.esxm.2020.100317.

35. Wu CC, Wu YN, Ho HO, Chen KC, Sheu MT, Chiang HS. The neuroprotective effect of platelet-rich plasma on erectile function in bilateral cavernous nerve injury rat model. J Sex Med. 2012;9(11):2838-48. PMID: 22906160. Available from: 10.1111/j.1743-6109.2012.02881.x.

36. Ding XG, Li SW, Zheng XM, Hu LQ, Hu WL, Luo Y. The effect of platelet-rich plasma on cavernous nerve regeneration in a rat model. Asian J Androl. 2009;11(2):215-21. PMID: 19151738. Available from: 10.1038/aja.2008.37.

37. Scott $S$, Roberts $M$, Chung E. Platelet-rich plasma and treatment of erectile dysfunction: critical review of literature and global trends in platelet-rich plasma clinics. Sex Med Rev. 2019;7(2):306-12. PMID: 30833169. Available from: 10.1016/j. sxmr.2018.12.006.

38. Epifanova M, Chalyi M, Krasnov A. Investigation of mechanisms of action of growth factors of autologous platelet-rich plasma used to treat erectile dysfunction. Urologiia (Moscow, Russia: 1999). 2017;1(4):46-8. Available from: 10.18565/ urology.2017.4.46-48.

39. Ruffo A, Stanojevic N, Romeo G, Riccardo F, Trama F, lacono F. PS-5-3 Management of Erectile Dysfunction Using a Combination Treatment of Low-Intensity Shock Waves (LISW) and Platelet Rich Plasma (PRP) Intracavernosal Injections. J Sex Med. 2020;17(6):133-4. Available from: 10.1016/j.jsxm.2020. 04.048 .

40. Tas T, Çakıroglu B, Arda E, Onuk Ö, Nuhoglu B. Early Clinical Results of the Tolerability, Safety, and Efficacy of Autologous Platelet-Rich Plasma Administration in Erectile Dysfunction. Sex Med. 2021;9(2):100313. PMID: 33529814. Available from: $10.1016 /$ j.esxm.2020.100313. 
41. Poulios E, Mykoniatis I, Pyrgidis N, Zilotis F, Kapoteli P, Kotsiris D. Platelet-Rich Plasma (PRP) Improves Erectile Function: A Double-Blind, Randomized, Placebo-Controlled Clinical Trial. J Sex Med. 2021;18(5):926-35. PMID: 33906807. Available from: 10.1016/j.jsxm.2021.03.008.

42. Feldman HA, Goldstein I, Hatzichristou DG, Krane RJ, McKinlay JB. Construction of a surrogate variable for impotence in the Massachusetts Male Aging Study. J Clin Epidemiol. 1994;47(5):457-67. PMID: 7730871. Available from: 10.1016/ 0895-4356(94)90292-5.

43. Vlachopoulos C, Aznaouridis K, loakeimidis N, Rokkas K, Vasiliadou C, Alexopoulos N. Unfavourable endothelial and inflammatory state in erectile dysfunction patients with or without coronary artery disease. Eur Heart J. 2006;27(22):2640-8. PMID: 17056702. Available from: 10.1093/eurheartj/ehl341.

44. Bahk JY, Jung JH, Han H, Min SK, Lee YS. Treatment of diabetic impotence with umbilical cord blood stem cell intracavernosal transplant: preliminary report of 7 cases. Exp Clin Transplant. 2010;8(2):150-60. PMID: 20565373.

45. Haahr MK, Jensen CH, Toyserkani NM, Andersen DC, Damkier P, Sørensen JA. Safety and potential effect of a single intracavernous injection of autologous adipose-derived regenerative cells in patients with erectile dysfunction following radical prostatectomy: an open-label phase I clinical trial. EBioMedicine. 2016;5:204-10. PMID: 27077129. Available from: 10.1016/j.ebiom.2016.01.024.

46. Haahr MK, Jensen $\mathrm{CH}$, Toyserkani NM, Andersen DC, Damkier $P$, Sørensen JA, et al. A 12-Month Follow-up After a Single Intracavernous Injection of Autologous Adipose-Derived Regenerative Cells in Patients with Erectile Dysfunction Following Radical Prostatectomy: An Open-Label Phase I Clinical Trial . Urology. 2018;121(203):e6-203.e13. PMID: 29958973. Available from: 10.1016/j.urology.2018.06.018.

47. Levy JA, Marchand M, lorio L, Cassini W, Zahalsky MP. Determining the Feasibility of Managing Erectile Dysfunction in Humans With Placental-Derived Stem Cells. J Am Osteopath Assoc. 2016;116(1):e1-5. PMID: 26745574.

48. Yiou R, Hamidou L, Birebent B, Bitari D, Lecorvoisier P, Contremoulins I. Safety of intracavernous bone marrowmononuclear cells for postradical prostatectomy erectile dysfunction: an open dose-escalation pilot study. Eur Urol. 2016;69(6):988-91. PMID: 26439886. Available from: 10.1016/ j.eururo.2015.09.026.

49. Yiou R, Hamidou L, Birebent B, Bitari D, Corvoisier PL, Contremoulins I. Intracavernous injections of bone marrow mononucleated cells for postradical prostatectomy erectile dysfunction: final results of the INSTIN clinical trial. Eur Urol Focus. 2017;3(6):643-5. PMID: 28753830. Available from: 10.1016/j.euf.2017.06.009.

50. Demour SA, Jafar $\mathrm{H}$, Adwan $\mathrm{S}$, AlSharif A, Alhawari $\mathrm{H}$, Alrabadi A. Safety and potential therapeutic effect of two intracavernous autologous bone marrow derived mesenchymal stem cells injections in diabetic patients with erectile dysfunction: an open label phase I clinical trial. Urol Int. 2018;101(3):35865. PMID: 30173210 . Available from: 10.1159/000492120.

51. You D, Jang MJ, Song G, Shin HC, Suh N, Kim YM, et al. Safety of autologous bone marrow-derived mesenchymal stem cells in erectile dysfunction: an open-label phase 1 clinical trial. Cytotherapy. 2021;23(10):931-8. PMID: 34326007. Available from: 10.1016/j.jcyt.2021.06.001.

52. Protogerou V, Michalopoulos E, Mallis P, Gontika I, Dimou Z, Liakouras $C$. Administration of adipose derived mesenchymal stem cells and platelet lysate in erectile dysfunction: a single center pilot study. Bioengineering (Basel). 2019;6(1):21. PMID:
30841525. Available from: 10.3390/bioengineering6010021.

53. Protogerou V, Beshari SE, Michalopoulos E, Mallis P, Chrysikos D, Samolis AA. The Combined Use of Stem Cells and Platelet Lysate Plasma for the Treatment of Erectile Dysfunction: A Pilot Study-6 Months Results. Medicines (Basel). 2020;7(3):14 PMID: 32197323. Available from: 10.3390/medicines7030014.

54. Bieri M, Said E, Antonini G, Dickerson D, Tuma J, Bartlett CE. Phase I and registry study of autologous bone marrow concentrate evaluated in PDE5 inhibitor refractory erectile dysfunction. J Transl Med. 2020;18(1):24. PMID: 31937310. Available from: 10.1186/s12967-019-02195-w.

55. Protogerou V, Chrysikos D, Karampelias V, Spanidis Y, Sara EB, Troupis T. Erectile Dysfunction Treatment Using Stem Cells: A Review. Medicines (Basel). 2021;8(1):2. PMID: 33419152. Available from: 10.3390/medicines8010002.

56. Chung E, Brock GB. Emerging and novel therapeutic approaches in the treatment of male erectile dysfunction. Cur Urol Rep. 2011;12(6):432-43. PMID: 21922167. Available from: 10.1007/s11934-011-0216-y.

57. Lin CS. Advances in stem cell therapy for erectile dysfunction. Advances in Andrology. 2014;2014:140618. Available from: 10.1155/2014/140618.

58. Chung E. Stem-cell-based therapy in the field of urology: a review of stem cell basic science, clinical applications and future directions in the treatment of various sexual and urinary conditions. Expert Opin Biol Ther. 2015;15(11):1623-32. PMID 26243575. Available from: 10.1517/14712598.2015.1075504.

59. Chung E. Stem cell therapy in diabetic men with erectile dysfunction: a step closer to safe and effective regenerative technology. Ann Transl Med. 2019;7(Suppl 1):S40. PMID: 31032319. Available from: 10.21037/atm.2019.02.28.

60. Bochinski D, Lin GT, Nunes L, Carrion R, Rahman N, Lin CS. The effect of neural embryonic stem cell therapy in a rat model of cavernosal nerve injury. BJU Int. 2004;94(6):904-9. PMID: 15476533. Available from: 10.1111/j.1464-410X.2003.05057.x.

61. Lin CS, Xin Z, Dai J, Huang YC, Lue TF. Stem-cell therapy for erectile dysfunction. Expert Opin Biol Ther. 2013;13(11):158597. PMID: 24090162. Available from: 10.1517/14712598.2013. 847085.

62. Hou QL, Ge MY, Zhang CD, Tian DD, Wang LK, Tian HZ. Adipose tissue-derived stem cell therapy for erectile dysfunction in rats: a systematic review and meta-analysis. Int Urol Nephrol. 2017;49(7):1127-37. PMID: 28417342. Available from: $10.1007 / \mathrm{s} 11255-017-1590-2$.

63. Bivalacqua TJ, Deng W, Kendirci M, Usta MF, Robinson C, Taylor BK. Mesenchymal stem cells alone or ex vivo gene modified with endothelial nitric oxide synthase reverse ageassociated erectile dysfunction. Am J Physiol Heart Circ Physiol. 2007;292(3):1278-90. PMID: 17071732. Available from: 10.1152/ajpheart.00685.2006.

64. Chen S, Zhu J, Wang M, Huang Y, Qiu Z, Li J, et al. Comparison of the therapeutic effects of adipose-derived and bone marrow mesenchymal stem cells on erectile dysfunction in diabetic rats. Int J Mol Med. 2019;44(3):1006-14. PMID: 31257465. Available from: 10.3892/ijmm.2019.4254.

65. Gur S, Abdel-Mageed AB, Sikka SC, Hellstrom WJ. Advances in stem cell therapy for erectile dysfunction. Expert Opin Biol Ther. 2018;18(11):1137-50. PMID: 30301368. Available from: 10.1080/14712598.2018.1534955.

66. Kim S, Cho MC, Cho SY, Chung H, Rajasekaran MR. Novel emerging therapies for erectile dysfunction. World J Mens Health. 2021;39(1):48-64. PMID: 32202086. Available from: $10.5534 /$ wjmh. 200007. 
Ready to submit your manuscript? Choose Biomedpress and benefit from:

- Fast, convenient online submission

- Through peer-review by experienced researchers

- Rapid publication on acceptance

- Free of charge (without publication fees)

Learn more http://www.biomedpress.org/journals/
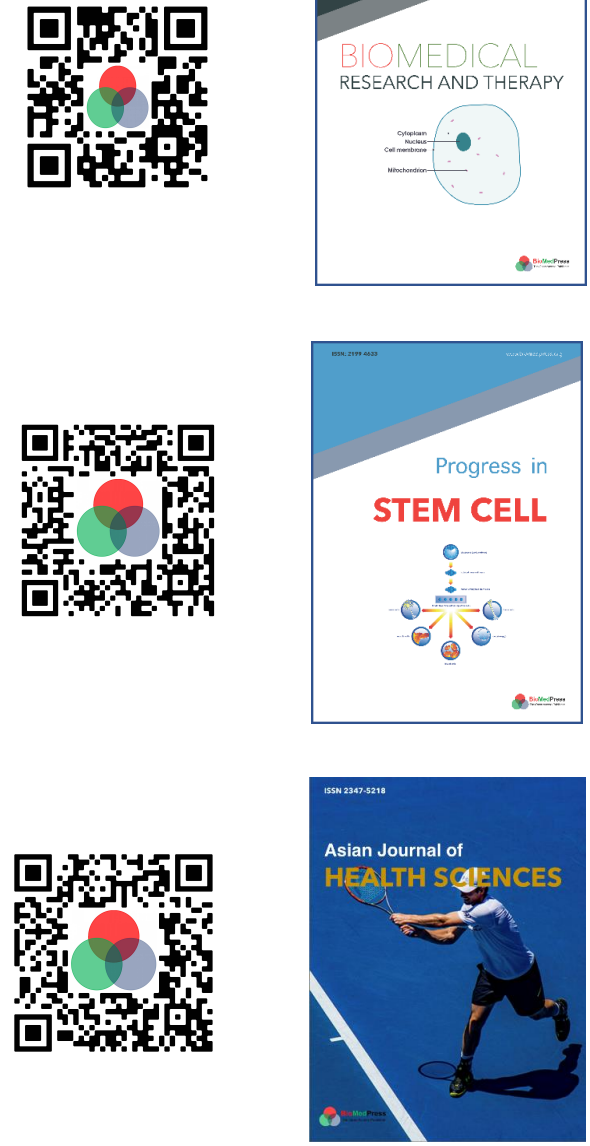

Asian Journal of Health Sciences

ISSN: 2347-5218

Indexed: Google Scholar

Acceptance Rate (2020): 72.89\%

Article Publishing Charge: Free

Submission to first editorial decision: 16.5 days

Biotechnological Research

ISSN: 2395-6763

Indexed: Google Scholar

Acceptance Rate (2020): $67.02 \%$

Article Publishing Charge: Free

Submission to first editorial decision: 28.5 days 